\title{
Pracownik czy przedsiębiorca? Teoria wyboru zajęcia zawodowego w wyjaśnianiu decyzji o formie aktywności zawodowej
}

\section{Employee or entrepreneur? Theory of occupational choice in explaining the decision about the form of professional activity}

\author{
prof. dr hab. Aleksandra Gawef \\ Uniwersytet Ekonomiczny w Poznaniu, Katedra Konkurencyjności Międzynarodowej \\ ORCID 0000-0002-7426-3474 \\ e-mail: Aleksandra.Gawel@ue.poznan.pl
}

\begin{abstract}
Streszczenie Teoria wyboru zajęcia zawodowego zakłada, że dana osoba może wybrać formę aktywności zawodowej pomiędzy byciem przedsiębiorcą a pracownikiem najemnym. Zgodnie z ujęciem neoklasycznym, wskazuje się na korzyści i koszty każdego z wyborów. Korzyścią dla pracownika jest uzyskanie wynagrodzenia za pracę pozbawione ryzyka, a dla przedsiębiorcy — zysk przedsiębiorczy obarczony ryzykiem niepowodzenia. Natomiast kosztami są koszty zaangażowania kapitału ludzkiego przy obu wyborach, zaś w przypadku przedsiębiorców również koszt kapitału finansowego i społecznego. Postrzeganie tych korzyści i kosztów jest uzależnione od wewnętrznych motywacji, takich jak np. skłonność do ryzyka, oraz od czynników zewnętrznych, jak choćby sytuacja na rynku pracy. Ostateczny wybór jest dyktowany dążeniem do maksymalizacji różnicy między korzyściami i kosztami. Osoby, które postrzegają ryzykowny zysk przedsiębiorczy jako bardziej prawdopodobnie wyższy niż wynagrodzenie, decydują o wejściu do przedsiębiorczości. W przeciwnym wypadku zostają pracownikami.
\end{abstract}

Słowa kluczowe: przedsiębiorca, teoria wyboru zajęcia zawodowego, ekonomia neoklasyczna.

Summary Theory of occupational choice assumes that a given person can choose the form of professional activity between being an entrepreneur and paid employee. According to the neoclassical attitude, each choice is connected with benefits and costs. Employee gets risky-free salary while an entrepreneur earns entrepreneurial profit characterized by risk of failure. Costs of human capital are costs of both forms while entrepreneurs also bear costs of financial capital and social capital. Perception of those benefits and costs depend on internal motivation such as for example the propensity towards risk and external factors as for example labour market situation. The final occupational choice depends on the pursuance of maximization of difference between benefits and costs. Persons who perceive risky entrepreneurial profit as likely higher than salary decide to enter to entrepreneurship. In another case, they decide to become paid employees.

Keywords: entrepreneur, occupational choice theory, neoclassical economics.

JEL: L26, D9

str. $2-9$

\section{Bibliografia}

Andersson Joona, P. Wadensjo, E. (2013). The best and the brightest or the least successful? Self-employment entry among male wage-earners in Sweden. Small Business Economics, 40, 155-172, http://doi.10.1007/s11187-011-9365-0

Atalay, K. Kim, W.-Y. Whelan, S. (2014). The Decline of the Self-Employment Rate in Australia. The Australian Economic Review, 
47(4), 472-489.

Banerjee, A. V. Newman, A. F. (1993). Occupational Choice and the Process of Development. Journal of Political Economy, 101(2), 274-298.

Begg, D. Fischer, S. Dornbusch, R. (1993). Ekonomia. Tom 1. Warszawa: PWE.

Bennett, J. Rablen, M. D. (2015). Self-employment, wage employment, and informality in a developing economy. Oxford Economic Papers, 67(2), 227-244, http://doi.10.1093/oep/gpu-047

Bianchi, M. Bobba, M. (2013). Liquidity, Risk, and Occupational Choices. Review of Economic Studies, 80, 491-511, doi.10.1093/restud/rds031

Blumberg, B. F. Letteries, W. A. (2008). Business Starters and Credit Rationing. Small Business Economics, 30, $187-200$.

Bradley, J. (2016). Self-employment in an equilibrium model of the labor market. IZA Journal of Labor Economics, 5(6), http://doi.10.1186/s40172-016-0046-8

Brown, S. Farrell, L. Harris, M. N. (2011). Modeling the Incidence of Self-Employment: Individual and Employment Type Heterogeneity. Contemporary Economic Policy, 29(4), 605-619, http://doi.10.1111/J.1465-7287.2010.00232

Crum, M. Chen, Y. (2015). Self-Employment and Subjective Well-Being: A Multi-Country Analysis. International Journal of Entrepreneurship, 19, 15-28.

Dawson, Ch. Henley, A. Latreille, P. (2014). Individual Motives for Choosing Self-employment in the UK: Does Region Matter? Regional Studies, 48(5), 804-822, http://dx.doi. org/10.1080/00343404.2012.697140.

Feinberg, R. M. (1978). On the Empirical Importance of the Job Search Theory. Southern Economic Journal, 45(2), 508-521.

Gelderen van, M. Thurik, R. Bosma, N. (2006). Success and Risk Factors in the Pre-Startup Phase. Small Business Economics, 26, 319-335.

Hyytinen, A. Vaananen, L. (2006). Where do Financial Constraints Originate from? An Empirical Analysis of Adverse Selection and Moral Hazard in Capital Markets. Small Busi-ness Economics, 27, 323-348.

Kihlstrom, R. E. Laffont, J.-J. (1979). A General Equilibrium Entrepreneurial Theory of Firm Formation Based on Risk Aversion. Journal of Political Economy, 87(4), 719-748.

Krasniqi, B. A. (2014). Characteristics of Self-Employment: A Refuge from Unemployment or Road to Entrepreneurship. Small Enterprise Research, 21(1), 33-53.

Krugman, P. Wells, R. (2016). Mikroekonomia. Warszawa: Wy- dawnictwo Naukowe PWN.

Le, A. T. Miller, P. W. Slutske, W. S. Martin, N. G. (2014). Attitudes Toward Economic Risk and Occupational Choice. Industrial Relations, 53(4), 568-592.

Mankiw, G. N. Taylor, M. P. (2009). Makroekonomia. Warszawa: PWE.

McClough, D. Hoag, J. Benedict, M. E. (2014). What Matters, and How: Does Procedural Utility Explain Self-employment? Academy of Entrepreneurship Journal, 20(2), 103-120.

Medrano-Adań, L. Salas-Fumaś, V. Sanchez-Asin, J. J. (2015). Heterogeneous entrepreneurs from occupational choices in economies with minimum wages. Small Business Economics, 44, 597-619, http://doi.10.1007/s11187-014-9610-4.

Millan, J. M. Congregado, E. Roman, C. (2012). Determinants of self-employment survival in Europe, 38, 231-258, http://doi.10.1007/s11187-010-9260-0.

Minola, T. Criaco, G. Obschonka, M. (2016). Age, culture, and self-employment motivation. Small Business Economics, 46, 187-213, http://doi.10.1007/s11187-015-9685-6.

Modrego, F. Mccann, Ph. Foster, W. E. M. Rose Olfert, M. R. (2017). Location and Entrepreneurship: Insights from a SpatiallyExplicit Occupational Choice Model with an Application to Chile. Journal of Regional Science, 57(4), 669-697, http://doi.10.1111/Jors.12323

Moulton, J. G. Scott, J. C. (2016). Opportunity or Necessity? Disaggregating Self-Employment and Entry at Older Ages. Social Forces, 94(4), 1539-1566, http://doi.10.1093/sf/ sow026

Pardo, C. Ruiz-Tagle, J. (2017). The dynamic role of specific experience in the selection of self-employment versuswageemployment. Oxford Economic Papers, 69(1), 189-212, http://doi.10.1093/oep/gpw047

Paulson, A. L. Townsend, P. M. Karaivanov, A. (2006). Distinguishing Limited Liability from Moral Hazard in a Model of Entrepreneurship. Journal of Political Economy, 114, 100-144.

Rekowski, M. (2005). Mikroekonomia. Poznań.

Reynolds, P. D. (2011). Informal and Early Formal Financial Support in the Business Creation Process: Exploration with PSED II Data Set. Journal of Small Business Management, 49(1), 27-54.

Seghers, A. Manigart, S. Uanacker, T. (2012). The Impact of Human and Social Capital on Entrepreneurs' Knowledge of Finance Alternatives. Journal of Small Business Management, 50(1), 63-86.

Simoes, N. Crespo, N. Moreira, S. B. (2016). Individual Determinants of Self-Employment Entry: What do We Really Know? Journal of Economic Surveys, 30(4), 783-806, http://doi.10.1111/joes.12111

Smith, A. (2015). Badania nad naturą i przyczynami bogactwa narodów (polskie wyd. 2015, wyd. pierwsze 1776).

Startiene, G. Remeikiene, R. Dumčiuviene, D. (2010). Concept of Self-Employment. Economics and Management, 15, $262-274$.

Svaleryd, H. (2015). Self-employment and the local business cycle. Small Business Economics, 44, 55-70, http://doi.10.1007/s11187-014-9592-2

Zaretsky, A. M. Coughlin, C. C. (1995). An Introduction to the Theory and Estimation of a Job-Search Model. Federal Reserve Bank of St. Louis Review, 77(1), 53-6 